\title{
The Prognostic Role of Anemia in Heart Failure Patients
}

\author{
TUDOR PARVANESCU\#, BOGDAN BUZ\#, DIANA AURORA BORDEJEVIC*, FLORINA CARUNTU, \\ MIHAI TROFENCIUC, MIRELA CLEOPATRA TOMESCU, IOANA MIHAELA CITU \\ "Victor Babes" University of Medicine and Pharmacy, Cardiology Department, 2 Eftimie Murgu Sq., 300041, \\ Timisoara, Romania
}

\begin{abstract}
Anemia is frequently observed in heart failure $(H F)$ patients. The aim of this prospective study was to assess if it is an independent predictor of outcome or a marker of a worse clinical condition in these patients. The study included 134 heart failure patients aged over 18 years. The patients were divided into two groups, according to the presence or absence of anemia at hospital admission. Anemia was defined as a hemoglobin concentration of less than $12 \mathrm{~g} / \mathrm{dl}$ for women and less than $13 \mathrm{~g} / \mathrm{dl}$ for men. The endpoints were: length of hospitalization, all cause-death during hospitalization, and all-cause death and HF rehospitalizations at 1 year. Anemia occurred in 33\% of HF patients. The HF patients with anemia were significantly older, had more often ischemic etiology of heart failure and atrial fibrillation, chronic kidney disease and 3 or more comorbidities. The length of hospitalization was similar between the two groups. Deaths during hospitalization occurred in $13 \%$ of anemic and in $3 \%$ of the nonanemic patients $(P=0.04)$. During the 1-year follow-up, $45 \%$ of the anemic vs. $28 \%$ of the nonanemic patients were rehospitalized due to aggravated HF $(P=0.04)$, and $14 \%$ of the anemic vs $20 \%$ of the nonanemic patients died $(P=0.38)$. Anemia was strongly predictive for in-hospital and 1 - year all-cause deaths in univariate analysis, but not in multivariate analysis. Anemia seems more a marker of a worse clinical condition, rather than an independent risk factor in $\mathrm{HF}$.
\end{abstract}

Keywords: anemia, heart failure, prognosis

Heart failure is a serious condition that requires medical care. Identification and prevention of the risk factors play an important role for congestive heart disease. [1-3] Anemia is a common comorbidity found in heart failure and it is associated with a worse prognosis. The mechanisms by which it influences the evolution of HF are not well known. [4-9] There are encouraging iron treatment results that presents good outcome for HF, but so far there have been no conclusive mortality data. [10-13] As such, there are still unclear aspects regarding the clinical implications of anemia in heart failure. The present study aims to assess the prevalence of anemia in HF patients, to compare clinical characters and the evolution of index hospitalization in patients with and without anemia. Also, the study wants to determine the impact of anemia on major cardiovascular events in the short term and 1 year follow up in congestive heart failure.

\section{Experimental part}

\section{Material and methods}

The study included 139 patients with heart failure, aged $\geq 18$ years, and without any other exclusion criteria. The hospital ethics committee approved the study. All the patients included signed informed consent to their participation in the study.

Patients were divided into 2 groups, depending on the hemoglobin $(\mathrm{Hb})$ plasma concentration at admission. According to OMS criteria, anemia was defined as serum $\mathrm{Hb}<13 \mathrm{~g} / \mathrm{dL}$ for men and $<12 \mathrm{~g} / \mathrm{dL}$ for women.

Anemic and non-anemic patients were compared on basal clinical characteristics, hospital treatment, evolution during index hospitalization (duration of hospitalization, mortality) and up to 1 year (mortality of all causes and hospitalization due to worsening of heart failure).

The statistical analysis was performed using the MedCalc statistical software version 12.3.0.0 program for Windows. The categorical variables are presented as number and percent, and the continuous variables are presented as mean and standard deviation (SD). The significance of the differences between the two groups was calculated by the Fisher for the categorical variables and the Mann-Whitney $U$ test for the continuous variables.

The predictive factors for events were identified with the Cox proportional risk regression model, the univariable and multivariate logistic regression analysis. The multivariate analysis included all variables that had statistical significance in univariate analysis. The rates of hospitalization and mortality were compared using the Kaplan Meyer curves. For all tests, the value of $p>0.05$ was considered statistically significant. All tests were two tailed. 


\section{Results and discussions}

Figure 1 shows the enrollment scheme of patients in the study. The study group has 139 patients with heart failure, with an average age of 69 years ( \pm 9 years). The median $\mathrm{Hb}$ plasma concentration at admission was $13.4 \mathrm{~g} / \mathrm{dL}$ (Interquartile interval: 12.0-14.5 g / dL). Anemia was present at admission in 46 of 139 patients with HF (33\%).

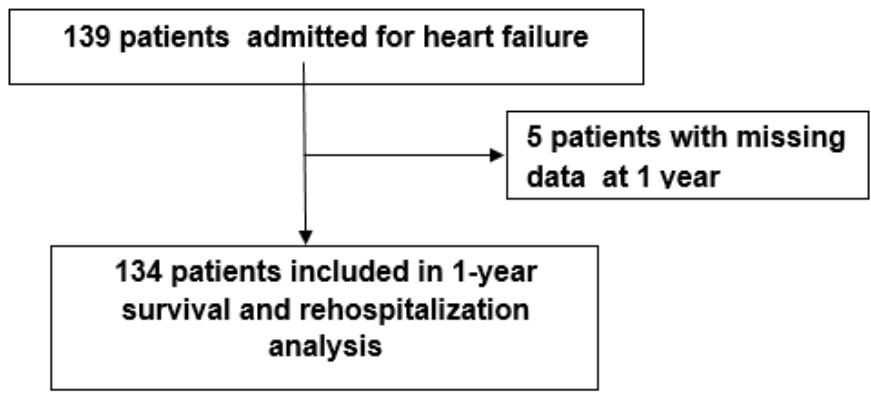

Fig. 1. Flow chart of patient enrollment in the current analysis

The clinical characteristics of anemic and non-anemic patients with heart failure are presented in tables 1 and 2. Patients with anemia were significantly older, with lower body mass index (BMI), also with a higher prevalence of ischemic etiology of heart failure, atrial fibrillation, chronic kidney disease, and more than three comorbidities. Compared with the other group, the patients from group I had significantly higher anticoagulant and/or platelet antiaggregant treatment (Table 1), had higher heart rates and lower systolic blood pressure, and infections which caused decompensation of heart failure more frequently (Table 2 ).

As for laboratory data, patients in group I showed significantly lower levels of hemoglobin and glomerular filtration rate, and higher creatinine and serum potassium values (Table 3).

The hemoglobin concentration between hospitalization and discharge were as follows: 20 (15\%) increased by over $1 \mathrm{~g} / \mathrm{dL}, 20(15 \%)$ decreased and $97(70 \%)$ remained unchanged.

At discharge, anemic patients showed significantly higher heart rate and lower systolic blood pressure compared to non-anemic (Table 4) and also higher serum creatinine and serum potassium, lower serum hemoglobin, glomerular filtration rate and serum sodium.

Table 1

HISTORY AND MEDICAL TREATMENT OF PATIENTS WITH HEART FAILURE AT INDEX HOSPITALIZATION

\begin{tabular}{|c|c|c|c|}
\hline Parameter & $\begin{array}{l}\text { Group I (anemia) } \\
n=46\end{array}$ & $\begin{array}{c}\text { Group II } \\
\text { (non-anemia) } \\
n=93\end{array}$ & Pvalue \\
\hline \multicolumn{4}{|l|}{ Clinical data } \\
\hline Age (years) & $71.8 \pm 20.6$ & $68 \pm 9.2$ & $<0.0001$ \\
\hline Male gender & $32(69 \%)$ & $60(65 \%)$ & 0.69 \\
\hline Body Mass Index $\left(\mathrm{kg} / \mathrm{m}^{2}\right)$ & $27 \pm 2.4$ & $28.0 \pm 2.4$ & 0.06 \\
\hline A previous hospitalization due to $\mathrm{HF}$ & $28(61 \%)$ & $47(51 \%)$ & 0.27 \\
\hline Idiopathic dilated cardiomyopathy & $4(9 \%)$ & $14(15 \%)$ & 0.32 \\
\hline Ischemic etiology of heart failure & $29(63 \%)$ & $39(42 \%)$ & 0.02 \\
\hline $\begin{array}{l}\text { Previous intervention of myocardial } \\
\text { revascularization (PCI or aortic coronary bypass) }\end{array}$ & $17(37 \%)$ & $29(31 \%)$ & 0.48 \\
\hline Valvular etiology of heart failure & $7(15 \%)$ & $11(12 \%)$ & 0.62 \\
\hline -Aortic stenosis & $2(4 \%)$ & $3(3 \%)$ & 0.75 \\
\hline -Aortic regurgitation & $2(4 \%)$ & $2(2 \%)$ & 0.49 \\
\hline -Mitral regurgitation & $3(6 \%)$ & $6(6 \%)$ & 1.0 \\
\hline Essential hypertension & $33(72 \%)$ & $62(66 \%)$ & 0.47 \\
\hline Atrial Fibrillation & $23(50 \%)$ & $30(32 \%)$ & 0.04 \\
\hline Peripheral obliterans arteriopathy & $7(15 \%)$ & $10(9 \%)$ & 0.29 \\
\hline Diabetes & $19(41 \%)$ & $29(31 \%)$ & 0.24 \\
\hline Chronic kidney disease & $15(35 \%)$ & $16(17 \%)$ & 0.02 \\
\hline Chronic obstructive pulmonary disease & $12(36 \%)$ & $14(19 \%)$ & 0.34 \\
\hline History of stroke & $5(11 \%)$ & $10(9 \%)$ & 0.70 \\
\hline 3 or more non-cardiac comorbidities & $6(14 \%)$ & $4(4 \%)$ & 0.03 \\
\hline Smoker & $25(54 \%)$ & $52(56 \%)$ & 0.82 \\
\hline \multicolumn{4}{|l|}{ Medication prior to admission } \\
\hline Furosemide & $31(67 \%)$ & $59(63 \%)$ & 0.64 \\
\hline Spironolactone & $19(41 \%)$ & $40(43 \%)$ & 0.82 \\
\hline ACEI & $27(59 \%)$ & $57(61 \%)$ & 0.82 \\
\hline Angiotensin receptor blocker & $3(7 \%)$ & $8(8 \%)$ & 0.82 \\
\hline Beta-blocker adrenergic & $33(72 \%)$ & $67(72 \%)$ & 1.0 \\
\hline Statin & $25(54 \%)$ & $49(53 \%)$ & 0.91 \\
\hline Anticoagulant & $23(50 \%)$ & $30(32 \%)$ & 0.04 \\
\hline Platelet antiaggregant & $25(54 \%)$ & $33(35 \%)$ & 0.03 \\
\hline
\end{tabular}

Abbreviations: $\mathrm{PCI}$, percutaneous coronary angioplasty; $\mathrm{ACEI}$, angiotensine-converting enzyme inhibitor 
Table 2

CLINICAL CONDITION AT HOSPITALIZATION OF PATIENTS WITH HEART FAILURE AT INDEX HOSPITALIZATION

\begin{tabular}{|c|c|c|c|}
\hline Parameter & $\begin{array}{c}\text { Group I (anemia) } \\
\mathbf{n = 4 6}\end{array}$ & $\begin{array}{c}\text { Group II } \\
\text { (non-anemia) } \\
\mathbf{n = 9 3}\end{array}$ & $\begin{array}{c}\text { P } \\
\text { value }\end{array}$ \\
\hline Heart rate (beats/min) & $97.3 \pm 26$ & $79 \pm 19$ & $<0.0001$ \\
\hline Systolic blood pressure (mmHg) & $120 \pm 26$ & $130 \pm 27$ & 0.03 \\
\hline Acute pulmonary edema & $4(9 \%)$ & $10(11 \%)$ & 0.72 \\
\hline Cardiogenic shock & $1(2 \%)$ & $2(2 \%)$ & 1.0 \\
\hline LVEF (\%) at admission & $37(25-50)$ & $36(25-50)$ & 0.82 \\
\hline NYHA functional class III & $22(48 \%)$ & $42(45 \%)$ & 0.74 \\
\hline NYHA functional class IV & $16(35 \%)$ & $39(42 \%)$ & 0.93 \\
\hline Atrial fibrillation as a cause of HF & $11(24 \%)$ & $23(25 \%)$ & 1.0 \\
\hline decompensation & $1(2 \%)$ & $2(2 \%)$ & 0.03 \\
\hline Ventricular tachycardia & $25(54 \%)$ & $33(35 \%)$ & 0.78 \\
\hline Anfection as a cause of HF decompensation & $8(17 \%)$ & $18(19 \%)$ & \\
\hline \multicolumn{2}{|c|}{ Abbreviations: NYHA, New York Heart Association; HF, heart failure; LVEF, left ventricular ejection fraction } \\
\hline
\end{tabular}

Table 3

LABORATORY DATA OF PATIENTS WITH HEART FAILURE AT INDEX HOSPITALIZATION

\begin{tabular}{|c|c|c|c|}
\hline Parameter & $\begin{array}{c}\text { Group I (anemia) } \\
\mathbf{n = 4 6}\end{array}$ & $\begin{array}{c}\text { Group II } \\
\text { (non-anemia) } \\
\mathbf{n = 9 3}\end{array}$ & Pvalue \\
\hline Hemoglobin (g/d) & $10.4 \pm 1.3$ & $14.0 \pm 0.6$ & $<0.0001$ \\
\hline Serum creatinine (mg/d) & $1.5 \pm 0.5$ & $1.07 \pm 0.35$ & $<0.0001$ \\
\hline Glomerular filtration rate $\left(\mathrm{ml} / \mathrm{min} / 1.73 \mathrm{~m}^{2}\right)$ & $58.3 \pm 19$ & $79.7 \pm 23$ & $<0.0001$ \\
\hline Plasma sodium (mEq/1) & $138 \pm 1$ & $139 \pm 1$ & 0.06 \\
\hline Potassium (mEq/1) & $4.6 \pm 0.3$ & $4.0 \pm 0.4$ & $<0.0001$ \\
\hline
\end{tabular}

Table 4

TREATMENT AND EVOLUTION OF PATIENTS WITH HEART FAILURE DURING INDEX HOSPITALIZATION

\begin{tabular}{|c|c|c|c|}
\hline Parameter & $\begin{array}{l}\text { Group I (anemia) } \\
\mathbf{n}=46\end{array}$ & $\begin{array}{c}\text { Group II } \\
\text { (non-anemia) } \\
\text { n=93 }\end{array}$ & Pvalue \\
\hline \multicolumn{4}{|l|}{ Pharmaceutical treatment } \\
\hline Inotropic iv & $7(16 \%)$ & $8(9 \%)$ & 0.22 \\
\hline Diuretics iv & $35(77 \%)$ & $58(62 \%)$ & 0.07 \\
\hline Nitrate iv & $8(17 \%)$ & $12(13 \%)$ & 0.52 \\
\hline $\begin{array}{l}\text { Transfer for myocardial revascularization } \\
\text { (PCI or aortic coronary bypass) }\end{array}$ & $5(11 \%)$ & $13(14 \%)$ & 0.62 \\
\hline \multicolumn{4}{|l|}{ Clinical condition at discharge } \\
\hline Cardiac Heart rate (beats/min) & $81 \pm 8.5$ & $72 \pm 8$ & $<0.0001$ \\
\hline Systolic blood pressure (mmHg) & $115 \pm 12$ & $123 \pm 13$ & 0.001 \\
\hline NYHA functional class I & $3(7 \%)$ & $6(6 \%)$ & 0.82 \\
\hline NYHA functional class II & $25(54 \%)$ & $61(66 \%)$ & 0.17 \\
\hline NYHA functional class III & $17(37 \%)$ & $24(26 \%)$ & 0.18 \\
\hline NYHA functional class IV & $1(2 \%)$ & $2(2 \%)$ & 1.00 \\
\hline Hemoglobin (g/dl) & $11.6 \pm 0.6$ & $13.7 \pm 0.6$ & $<0.0001$ \\
\hline Serum creatinine (mg/dl) & $1.43 \pm 0.4$ & $1.14 \pm 0.3$ & $<0.0001$ \\
\hline Plasma sodium ( $\mathrm{mEq} / \mathrm{l})$ & $138.5 \pm 2.5$ & $138.1 \pm 2.6$ & 0.38 \\
\hline Potassium $(\mathrm{mEq} / \mathrm{l})$ & $4.4 \pm 0.2$ & $3.9 \pm 0.4$ & $<0.0001$ \\
\hline \multicolumn{4}{|l|}{$\begin{array}{l}\text { The recommended treatment for } \\
\text { discharge }\end{array}$} \\
\hline Furosemide & $40(88 \%)$ & $78(84 \%)$ & 0.53 \\
\hline Spironolactone & $19(41 \%)$ & $40(43 \%)$ & 0.82 \\
\hline ACEI & $27(59 \%)$ & $57(61 \%)$ & 0.82 \\
\hline Angiotensin receptor blocker & $3(7 \%)$ & $8(9 \%)$ & 0.83 \\
\hline Beta-blocker adrenergic & $33(72 \%)$ & $67(72 \%)$ & 1.00 \\
\hline Statin & $25(54 \%)$ & $49(53 \%)$ & 0.91 \\
\hline Anticoagulant & $23(50 \%)$ & $30(32 \%)$ & 0.04 \\
\hline
\end{tabular}

The discharge treatment was similar between the two groups, with the exception that there were more patients who received anticoagulation treatment in group I . 
Index hospitalization having a duration of more than 7 days was recorded in 60 patients (43\%), 21 out of 46 anemic patients (46\%) and 38 out of 93 non-anemic (41\%) patients (Table 5). The relative risk of prolonged hospitalization was 1.5 times higher for anemic patients, but the difference was not statistically significant. Predictive factors of prolonged index hospitalization are shown in Table 6. Two predictive factors of prolonged hospitalization were highlighted in univariate analysis (heart rate at hospitalization and infection), but none retained the value of independent predictive factor in multivariate analysis.

Table 5

MORTALITY AND MORBIDITY OF PATIENTS WITH HEART FAILURE

\begin{tabular}{|c|c|c|c|}
\hline Parameter & $\begin{array}{c}\text { Group I } \\
\text { (anemia) } \\
\mathbf{n = 4 6}\end{array}$ & $\begin{array}{c}\text { Group II } \\
\text { (non-anemia) } \\
\mathbf{n = 9 3}\end{array}$ & P value \\
\hline Index hospitalization & $21(46 \%)$ & $38(41 \%)$ & 0.57 \\
\hline Duration of hospitalization over 7 days & $6(13 \%)$ & $3(3 \%)$ & 0.04 \\
\hline Mortality in the hospital & $\begin{array}{c}\text { Group I } \\
\text { (anemia) } \\
\text { Data to 1 year }\end{array}$ & $\begin{array}{c}\text { Group II } \\
\text { (non-anemia) } \\
\mathbf{n = 9 0}\end{array}$ & Pvalue \\
\hline To I year & $20(45 \%)$ & $25(28 \%)$ & 0.04 \\
\hline Readmissions & $6(14 \%)$ & $19(20 \%)$ & 0.38 \\
\hline Deaths & & & \\
\hline
\end{tabular}

Table 6

PREDICTIVE FACTORS OF PROLONGED HOSPITALIZATION AT UNIVARIATE AND MULTIVARIATE ANALYSIS

\begin{tabular}{|c|c|c|c|c|}
\hline Parameter & \multicolumn{2}{|c|}{ Univariate analysis } & \multicolumn{2}{c|}{ Multivariate analysis } \\
\hline & Relative Risk (CI) & Pvalue & Relative risk & Pvalue \\
\hline HR at admission & $1.02(1.0064-1.0380)$ & 0.003 & $1.01(0.9975-1.0372$ & 0.08 \\
\hline Infection & $2.34(1.1692-4.7145)$ & 0.01 & $1.42(0.5777-3.5012)$ & 0.44 \\
\hline
\end{tabular}

During index hospitalization 9 patients died $(6 \%): 6(5 \%)$ were anemic and 3(2\%) were non-anemic,as shown in Table 5. The predictive factors of intra-hospital deaths are shown in Table 7. In the multivariate analysis, the predictive factors of hospital death at initial hospitalization were: anemia, chronic kidney disease, heart rate and systolic blood pressure at admission, infection as a worsening factor for heart failure and hospitalization over 7 days. In the multivariate analysis, heart rate at admission was the only independent predictive factor of death in the hospital $(\mathrm{P}=0.001)$. The receiver operating characteristic curve $(\mathrm{ROC})$ of this independent predictive factor is shown in Figure 2.

Table 7

PREDICTIVE FACTORS OF IN- HOSPITAL DEATHS IN UNIVARIATE AND MULTIVARIATE ANALYSIS

\begin{tabular}{|c|c|c|c|c|}
\hline Parameter & \multicolumn{2}{|c|}{ Univariate analysis } & \multicolumn{2}{c|}{ Multivariate analysis } \\
\hline & Relative Risk(CI) & Pvalue & Relative risk & P value \\
\hline Anemia & $4.5(1.0714-18.9004)$ & 0.03 & $0.5(0.0506-6.1131)$ & 0.63 \\
\hline CKD & $5(1.2538-19.9394)$ & 0.02 & $3.8(0.6396-23.5905)$ & 0.14 \\
\hline HR at admission & $1.06(1.0322-1.0925)$ & $<0.0001$ & $1.04(1.0104-1.0841)$ & 0.001 \\
\hline Infection & $1.6(0.4240-6.4348)$ & $<0.0001$ & $0.5(0.0995-3.4186)$ & 0.58 \\
\hline $\begin{array}{c}\text { Index hospitalization } \\
\text { over 7 days }\end{array}$ & 6.1 (1.2334-30.9747) & $\mathbf{0 . 0 1}$ & $2.7(0.2445-32.0538)$ & 0.40 \\
\hline Abbreviations: CKD, chronic kidney disease; HR, heart rate; CI, confidence interval & \\
\hline
\end{tabular}

Table 8

PREDICTIVE FACTORS OF ALL-CAUSE DEATHS AT 1 YEAR IN UNIVARIATE AND MULTIVARIATE-VARIABLE ANALYSIS

\begin{tabular}{|c|c|c|c|c|}
\hline Parameter & \multicolumn{2}{|c|}{ Univariate analysis } & \multicolumn{2}{c|}{ Multivariate analysis } \\
\hline & Relative Risk(CI) & Pvalue & Relative risk & P value \\
\hline $\begin{array}{c}\text { Anemia at index } \\
\text { admission }\end{array}$ & $0.3(0.1393-0.9652)$ & 0.03 & $0.5(0.0965-2.7800)$ & 0.44 \\
\hline $\begin{array}{c}\text { Hb value at index } \\
\text { discharge }\end{array}$ & $1.46(1.0073-2.1236)$ & 0.04 & $1.1(0.6093-2.2850)$ & 0.62 \\
\hline Abbreviations: Hb, hemoglobin; CI, confidence interval & & \\
\hline
\end{tabular}




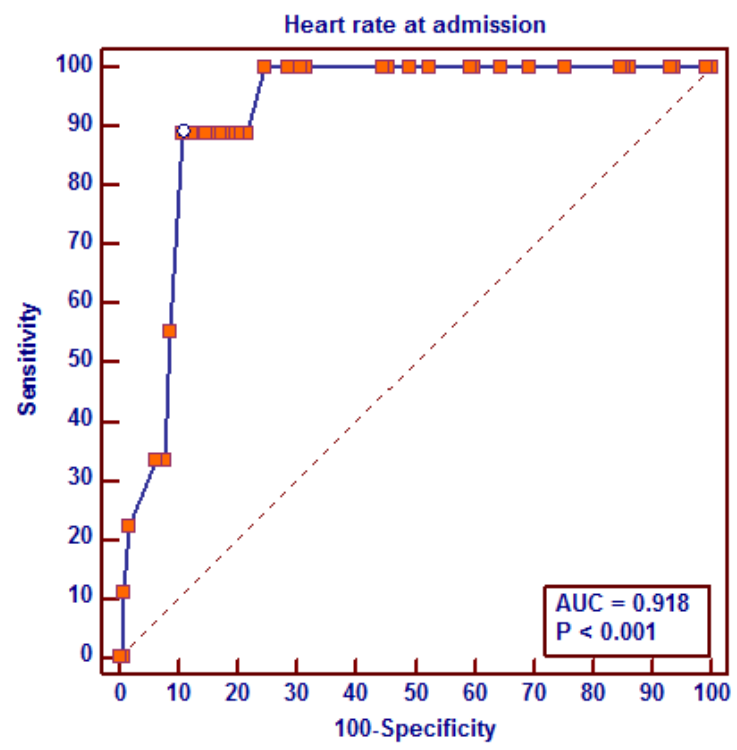

Fig. 2. Receiver Operating Characteristic (ROC) curve for heart rate at index admission as an independent predictive factor for in-hospital death of patients with heart failure ( $88 \%$ sensitivity, $89 \%$ specificity, index $\mathrm{J}=0.78$ )

1 year event data was available for 134 patients.

A total of 45 patients (34\%) were readmitted, of which 20 were anemic and 25 were non-anemic (Table 6). The Kaplan-Meyer curves for readmission to 1 year due to worsening of heart failure in anemic and non-anemic patients are shown in Figure 3. The difference between the curves is statistically significant. No predictive risk factors of oneyear readdmision were identified.

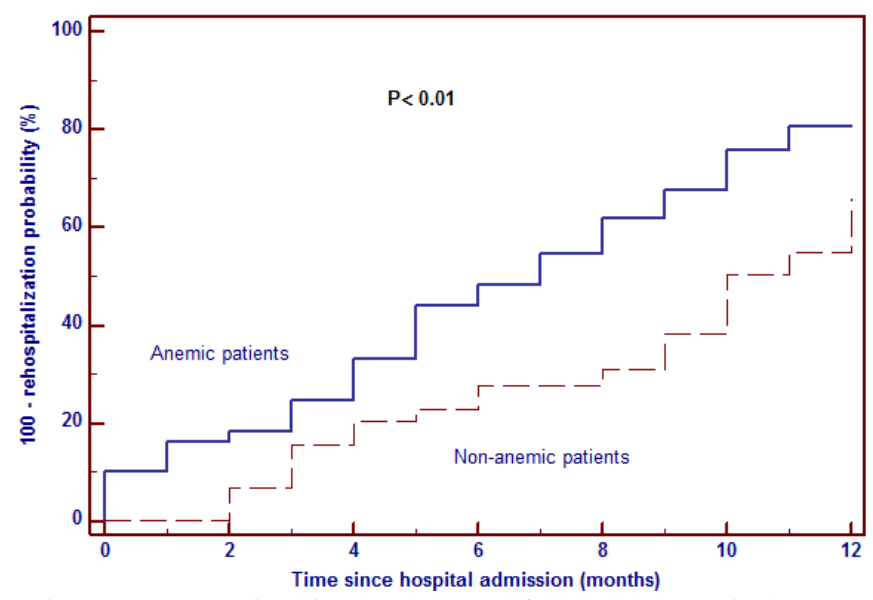

Fig. 3. Kaplan-Meier curves for heart failure rehospitalization al 1 year

25 patients (19\%) died in the 1-year follow-up period (6 were anemic and 19 non-anemic) (Table 5). The KaplanMeyer curves of deaths to 1 year of patients with heart failure, with and without anemia, are shown in Figure 4 . Tthe difference between the curves is statistically significant $(\mathrm{P}=0.02)$. Predictive factors of 1 -year death at univariate analysis were anemia at first admission and hemoglobin at first discharge, but none retained statistical significance for multivariate analysis (Table 8).

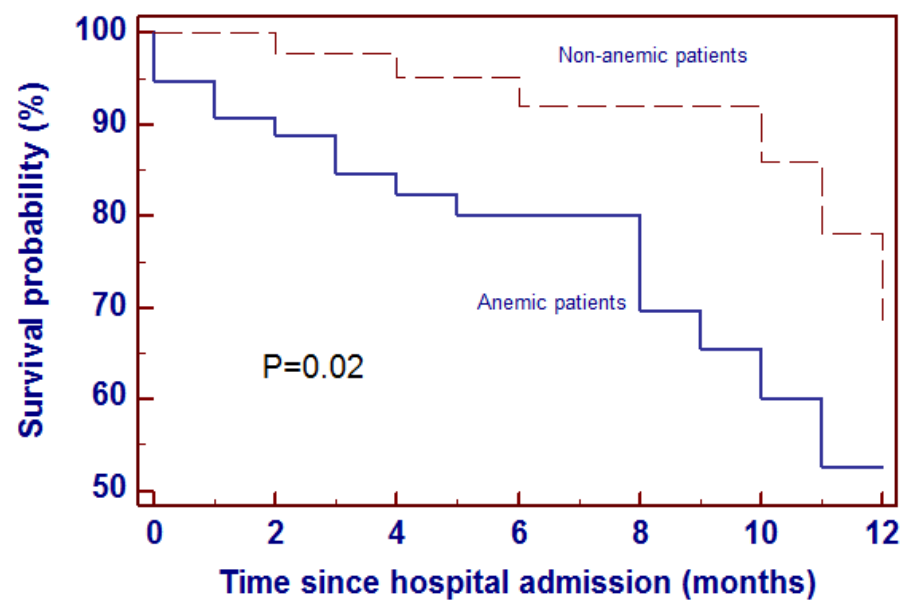

Fig. 4. Kaplan-Meier curves for all-cause death at 1 year

In various studies, the prevalence of anemia in patients with heart failure varies between 5 and $70 \%$, depending on the definition of anemia and patient selection [5,9]. In our study, the prevalence of anemia was $33 \%$, similar to that 
observed in the Swedish Registry of Heart Failure [6-13]. Other randomized clinical trials, which recruited significantly younger patients with IC, reported lower prevalence rates of 23-25\% [14,15].

Severe anemia is an exclusion criterion in most randomized trials, making it difficult to assess the actual prevalence of anemia.

There are several pathogenic mechanisms of anemia in heart failure [7,14,16-18].

Often, chronic kidney disease leads to anemia by reducing erythropoiesis [17].

In our study, patients with anemia (compared to those without anemia) were significantly older, with more frequent ischemic etiology of heart failure, had more frequent atrial fibrillation, chronic kidney disease, 3 or more associated co-morbidities, and anti-coagulant and/or anticoagulant treatment was more frequently followed. In multivariate analysis, none of these factors proved to be an independent predictor of anemia in heart failure. In severe heart failure, anemia may be secondary to iron deficiency due to malabsorption, nutritional deficiencies, or metabolic disorders of iron due to subclinical inflammation associated with hematopoietic depression [7,8,14].

In addition, in decompensated heart failure, increased plasma volume and hemodilution may explain higher prevalence of anemia. $[7,8]$ In our study, anemic patients had a higher prevalence of chronic kidney disease and as such significantly higher creatinine and serum potassium levels, and lower glomerular filtration rates. But the values of natremia have been similar to both groups, which excludes anemia by hemodilution. An important cause for decompensated heart failure was represented by the altered renal function. In the vast majority of cases, hyponatremia and hyperkalemia are direct consequence of the diuretic medication. These complications were not being related to the age of the patients [22].

A series of studies have shown that patients with heart failure and anemia receive less rarely on discharging treatment according to current recommendations of the Guidelines for Heart Failure [16,19,21]. In our study, treatment at discharge with adrenergic beta blockers, diuretics, anti-aldosterone or antagonists of the renin-angiotensinaldosterone system, did not show significant differences between patients with and without anemia. In contrast, the anticoagulant medication was significantly higher in anemic patients who also had a higher prevalence of atrial fibrillation. A meta-analysis including randomized trials revealed that there is a strong association between anemia and major cardiovascular events in congestive heart disease [6]. However, it is not known precisely whether anemia is an independent predictor of morbidity and mortality, or just a marker of a more severe clinical condition [14,16,20]. The results of this study suggest that although anemia was associated with a higher risk of death in hospital $(\mathrm{RR}=4.5)$ and death at 1 year $(\mathrm{RR}=0.4)$, multivariate analysis was not an independent predictive factor for these events. As such, it is rather a marker for an increased risk of poor outcome in patients with heart failure. Many factors associated with anemia, such as older age, chronic kidney disease, the association of multiple comorbidities, are also predictors of major cardiovascular events. In our study, the average age of patients with heart failure was 69 years, and in the subgroup of patients anemic for 71 years. These data are close to those reported by the Swedish Heart Failure Registry and EVEREST [13,16]. In contrast, in the randomized VAL-HEFT study and the IN-CHF registry, which included younger anemic patients (66-year-old, 67-year-old), anemia was an independent predictor of mortality and morbidity in heart failure [14,19]. Also in the Swedish Heart Failure Registry, the influence of anemia on mortality was much higher in younger patients. [13] In other studies and registries, anemia in the elderly was not significantly associated with the risk of death [9]. Similarly to our study, anemia was not an independent prognostic factor for mortality in multivariate analysis, although univariate analysis had a relative risk of almost 4.5 for hospital deaths and nearly 0.4 for deaths per year. This shows that although anemia is not a direct cause of all-cause deaths in patients with heart failure, its presence indicates a higher-risk category of patients requiring closer supervision.

Recent papers, that have studied intravenous iron treatment on patients with iron deficiency anemia and heart failure showed an improvement in the quality of life, exercise tolerance and NYHA functional class [10,11].

In addition, the CONFIRM-HF study showed a significant reduction in readmissions due to worsening of heart failure, with an insignificant reduction in mortality [12].

It should be noted, that iron treatment corrects not only anemia but also secondary muscular dysfunction due to iron deficiency [1]. A meta-analysis of the effects of erythropoiesis-stimulating therapies (with darbepoetine or erythropoietin) in patients with heart failure and mild to moderate anemia showed that these treatments reduced allcause deaths and readmissions [21].

\section{Conclusions}

These data seem to confirm that anemia is rather a marker of a poor clinical condition, including iron deficiency. As such, correction of plasma hemoglobin does not appear to be an objective of heart failure treatment.

Author contributions TP, BB, IMC, CMT-conception and design of the study, statistical analysis and interpretation of data, revising the manuscript for intellectual content, drafting the article; DAB - design of the manuscript, help in drafting manuscript, interpretation of data. FC, MT- acquisition and interpretation of data. All authors read and approved the final manuscript. 
Study limitations: the study was conducted in a single heart failure center, there are no data on causes of anemia, iron deficiency parameters and possible treatments.

\section{References}

1.PONIKOWSKI P, VOORS AA, ANKER SD, et al. Authors/Task Force Members; Document Reviewers. 2016 ESC Guidelines for the diagnosis and treatment of acute and chronic heart failure: the Task Force for the diagnosis and treatment of acute and chronic heart failure of the European Society of Cardiology (ESC). Developed with the special contribution of the Heart Failure Association (HFA) of the ESC. Eur Heart J 2016;37:2129-2200

2.GYALAI KI, ANCUSA O, DRAGOMIR T, et al. Factors associated with prolonged hospitalization, readmission, and death in elderly heart failure patients in western Romania. Clin Interv Aging. 2015 Mar 11;10:561-8. doi: 10.2147/CIA. 2001;110:582-584.

3.TRIBOUILLOY C, RUSINARU D, MAHJOUB H, et al. Prognosis of heart failure with preserved ejection fraction: a 5 year prospective population-based study, European Heart Journal, Volume 29, Issue 3, 1 February 2008, Pages 339- 347, https://doi.org 10.1093/ eurheartj/ ehm 554

4.CRESPO-LEIRO MG, ANKER SD, MAGGIONI AP, COATS AJ, FILIPPATOS G et al. Heart Failure Association (HFA) of the European Society of Cardiology (ESC). European Society of Cardiology Heart Failure Long-Term Registry (ESC-HF-LT): 1-year follow-up outcomes and differences across regions. Eur J Heart Fail 2016;18:613-625.

5.YOUNG JB, ABRAHAM WT, ALBERT NM, GATTIS STOUGH W,et al; OPTIMIZE-HF Investigators and Coordinators. Relation of low hemoglobin and anemia to morbidity and mortality in patients hospitalized with heart failure (insight from the PTIMIZE-HF registry). Am J Cardiol 2008;101:223-230.

6. GROENVELD HF, JANUZZI JL, DAMMAN K, VAN WIJNGAARDEN J, et al; Anemia and mortality in heart failure patients a systematic review and meta-analysis. J Am Coll Cardiol 2008; 52:818-827.

7.NANAS JN, MATSOUKA C, KARAGEORGOPOULOS D, LEONTI A,et al ; Etiology of anemia in patients with advanced heart failure J Am Coll Cardiol 2006;48:2485-2489.

8. JANKOWSKA EA, VON HAEHLING S, ANKER SD, MACDOUGALL IC, PONIKOWSKI P. Iron deficiency and heart failure: diagnostic dilemmas and therapeutic perspectives. Eur Heart J 2010;31:1872-1880.

9.KAJIMOTO K, SATO N, TAKANO T; Investigators of the Acute Decompensated Heart Failure Syndromes (ATTEND) registry. Association between anemia, clinical features and outcome in patients hospitalized for acute heart failure syndromes. Eur Heart J Acute Cardiovasc Care 2015;4:568-576.

10.BECK-DA-SILVA L, PIARDI D, SODER S, ROHDE LE, PEREIRA-BARRETTO AC,et al. IRON-HF study: a randomized trial to assess the effects of iron in heart failure patients with anemia. Int J Cardiol 2013;168:3439-3442.

11.GUTZWILLER FS, PFEIL AM, COMIN-COLET J, PONIKOWSKI P, FILIPPATOS G, MORI C, BRAUNHOFER PG, SZUCS TD, SCHWENKGLENKS M, ANKER SD. Determinants of quality of life of patients with heart failure and iron deficiency treated with ferric carboxymaltose: FAIR-HF sub-analysis. Int J Cardiol 2013;168:3878-3883

12.PONIKOWSKI P, VAN VELDHUISEN DJ, COMIN-COLET J, ERTL G, KOMAJDA M, ANKER SD, et al. CONFIRM-HF Investigators. Beneficial effects of long-term intravenous iron therapy with ferric carboxymaltose in patients with symptomatic heart failure and iron deficiencyt. Eur Heart J 2015;36: 657-668.

13.JONSSON A, HALLBERG AC, EDNER M, LUND LH, DAHLSTROM U. A comprehensive assessment of the association between anemia,clinical covariates and outcomes in a population-wide heart failure registry. Int J Cardiol 2016;211:124-131

14.ANAND IS, KUSKOWSKI MA, RECTOR TS, FLOREA VG, et al. Anemia and change in hemoglobin over time related to mortality and morbidity in patients with chronic heart failure: results from Val-HeFT. Circulation 2005;112:1121-1127.

15.O'MEARA E, CLAYTON T, MCENTEGART MB, MCMURRAY JJ, YUSUF S, SWEDBERG K, PFEFFER MA et al; CHARM Committees and Investigators. Clinical correlates and consequences of anemia in a broad spectrum of patients with heart failure: results of the Candesartan in Heart Failure: assessment of Reduction in Mortality and Morbidity (CHARM) Program. Circulation 2006;113:986-994.

16.MENTZ RJ, GREENE SJ, AMBROSY AP, VADUGANATHAN M, SUBACIUS HP, SWEDBERG K, MAGGIONI AP, NODARI S, PONIKOWSKI P, ANKER SD,BUTLER J, GHEORGHIADE M. Clinical profile and prognostic value of anemia at the time of admission and discharge among patients hospitalized for heart failure with reduced ejection fraction: findings from the EVEREST trial. Circ Heart Fail 2014;7:401-408.

17.PULIGNANO G, DEL SINDACO D, DI LENARDA A, TINTI MD, TARANTINI L, et al. Chronic renal dysfunction and anaemia are associated with cognitive impairment in older patients with heart failure. J Cardiovasc Med (Hagerstown) 2014;15:481-490.

18.LARINA VN, BART BI. Clinical manifestations of anemia syndrome and its significance in the course of chronic heart failure in elderly patients.Ter Arkh 2014;86:53-58.

19. MAGGIONI AP, OPASICH C, ANAND I et al. Anemia in patients with heart failure: prevalence and prognostic role in a controlled trial and in clinical practice. J Card Fail 2005;11:91-98.

20.SWEDBERG K, YOUNG JB, ANAND IS, CHENG S, DESAI AS, DIAZ R,MAGGIONI AP, MCMURRAY JJ, O'CONNOR C, PFEFFER MA, SOLOMON SD,SUN Y, TENDERA M, VAN VELDHUISEN DJ; RED-HF Committees; REDHF Investigators. Treatment of anemia with darbepoetin alfa in systolic heart failure. N Engl J Med 2013;368:1210-1219.

21.JANKOWSKA EA, TKACZYSZYN M, SUCHOCKI T, DROZD M, VON HAEHLING S, DOEHNER W, BANASIAK W, FILIPPATOS G, ANKER SD, PONIKOWSKI P.Effects of intravenous iron therapy in iron-deficient patients with systolic heart failure: a meta-analysis of randomized controlled trials. Eur J Heart Fail 2016;18:786-795.

22.AL NAMAT R., CONSTANTIN M., MIFTODE L, MANTA A., PETRIS A., MIFTODE R., COSTACHE AD., ILIESCU D., COSTACHE IR. Biochemical Markers in Patients with Readmission for Congestive Heart Failure, Rev. Chimia (Bucharest), 69,vol 7, July,2018, p1688.

Manuscript received: 30.05 .2019 